\title{
SOBRE 0 \& 81 DA ENCICLOPÉDIA E 0 CONCEITO DE CONTRADIÇÃO EM HEGEL
}

Eduardo Luft*

SÍNTESE - 0 autor mostra a especificidade do conceito de contradição em Hegel, a partir da análise do \& 81 da Enciclopédia. Em primeiro lugar, demonstra a importância deste conceito para a compreensão efetiva do método dialético. Em segundo lugar, a contradição dialética é apresentada como um conceito complexo, que não pode de modo algum ser confunaido com o uso deste termo em lógica formal (em afirmações do tipo $p$ $\left.\& \sim p^{\prime}\right)$. Além de conter um elemento pragmático, tal contradição é constituída por três modos diferentes de manifestaçäo, acompanhados de três sentidos diversos a serem especificados ao final do artigo.
ABSTRACT - In this article the author shows the specific character of Hegel's contradiction's concept, departing from the analisis of the \& 81 of the Encyclopedia. First he demonstrates the importance of this concept for the effective understanding of the dialectical method. Second, the dialectic contradiction is introduced as a complex concept, whose usage "cannot be confused with contradiction in formal logic (in affirmations like ' $p \& \sim p$ '). Such a contradiction contains a pragmatic element, but also is composed by three different manners of manifestation, with three different meanings specified at the end of article.

\section{1 - Introdução ao problema}

Há em Hegel, sem dúvida, um vínculo estrito entre contradição e método dialético. Este vínculo tem gerado inúmeros problemas, a partir das críticas formuladas primeiramente por A. Trendelenburg ${ }^{1}$ e, posteriormente, por K. Popper. ${ }^{2}$ Baseadas muito mais em compreensões distorcidas dos textos hegelianos, tais críticas vêm, no entanto, alertar para as dificuldades de compreensão deste conceito de importância central para a Dialética.

Não compreender o funcionamento da contradição equivale inevitavelmente a não apreender o modo particular do proceder dialético. Pois, se o conceito é a manifestação plena do logos dialético, "[...] princípio de toda a vida" (Enz, \& 160), a

\footnotetext{
Instituto de Filosofia e Ciências Humanas da PUCRS.

1 Cf. A. Trendelenburg, Logische Untersuchungen, Berlin, 1840.

2 Cf. K. R. Popper, "Que é a dialética?", in: Conjecturas e Refutaçöes, Brasília: Universidade de Brasília, 1972, p. 343 ss.

3 As obras de Hegel citadas são parte da edição de Eva Moldenhauer e Karl Marcus Michel, Frankfurt am Main, Suhrkamp, 1986, 20v. São elas: Enzyklopädie der philosophischen Wissenschaften, v. 8 (Enz), Phänomenologie des Geistes, v. 3 (PhG), e Wissenschaft der Logik, v. 6 (WL).
}

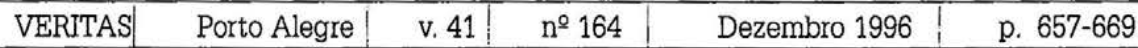


contradição é "[...] a raiz de todo o movimento e vitalidade [...]" (WL, 6, p. 75). Daí as dúvidas sobre o proceder da Dialética, que não partem só de seus críticos. ${ }^{4}$

É neste contexto que devemos interpretar a expressão de D. Henrich, ao início de seu Hegel im Kontext: "Quem quer compreender Hegel, está sempre sozinho consigo mesmo. [...] pode-se falar sobre a Dialética, mas não pensar [sobre ela], enquanto a obra principal de Hegel permanecer um livro cerrado". ${ }^{5}$ As dificuldades em definir a Dialética nos deixam entregues a nós mesmos, na tarefa de elucidar o emaranhado conceitual que se desdobra à nossa frente. Segundo N. Hartmann, "a Dialética é rara como é o dom do espírito; não é suscetível de aprendizagem, não tem em conta nem conhece as suas leis e, no entanto, é profundamente legal, objetiva e impugnável; como na criação artística genuína, tudo nela é necessário". ${ }^{6}$

Estaria a Dialética condenada a ser um método só utilizável por espíritos singulares e só acessível a aqueles que tivessem um dom similar? Não seria ela, então, a anti-filosofia, estando reservada a ser mais uma das criações ricas mas inefetivas do espírito humano?

Não compartilho desta visão redutora da Dialética, e nem da opinião dos comentadores que consideram as obras de Hegel um belo repertório de intuições geniais destituídas de um método efetivo. ${ }^{7}$ A Dialética é, desde Platão, muito mais do que um aglomerado destituído de rigor.

Partindo da análise do parágrafo 81 da Enciclopédia, este artigo procura lançar algumas luzes sobre o sentido da contradição em Hegel e, conseqüentemente, sobre as particularidades do método dialético.

4 Em seu recente livro, onde propõe uma reconstrução crítica da Lógica hegeliana, D. Wandschneider afirma: "A pergunta sobre o que seja a dialética foi muito discutida de modo controverso até hoje, mas permanece sem uma resposta satisfatória" (Grundzüge einer Theorie der Dialektik, Stuttgart, Klett-Cotta, 1995, p. 9).

D. Henrich, Hegel im Kontext, Frankfurt am Main, 1967, p. 7.

N. Hartmann, A Filosofia do Idealismo Alemão, p. 309.

Cf. as afirmações enfáticas de W. Kaufmann: "Existe no exterior a lenda de que o estudioso de Hegel terminará por escolher entre o sistema e a dialética [...]. Porém, não recuso esta última, de modo algum, para ficar com aquele: descreio de ambos. [...] busque-se a ela (a dialética) com prazer, vejase 0 que Hegel disse dela, e observe-se o que de fato leva a cabo; serão encontradas algumas observações sugestivas (não todas no mesmo tom) e toda a classe de afetações, porém não se achará nenhum método claro que se pudesse adotar se alguém quisesse fazê-lo" (Hegel, Madrid, Alianza Editorial, 1985, p. 169). Kaufmann tem razão ao descrer da existência de um método rigoroso em Hegel, através do qual se possa fazer predições (p. 170), mas é dificilmente aceitável a idéia básica de um Hegel sem método. É o próprio Hegel quem nos afirma incisivamente a importância do método dialético para a estruturação lógica de suas obras. Mas a negação da Dialética como método rigoroso é essencial: C. Taylor proporá a idéia de uma "dialética interpretativa" em lugar da "ciência dialética" (do marxismo ortodoxo), sendo esta diferenciação importante para a recusa de um regime político despótico: "Na linguagem de Aristóteles, nós poderíamos dizer que um conceito de dialética interpretativa pode formar a base de um regime político atual [não despótico], enquanto uma ciência dialética fornece antes a base para um regime despótico" ("Dialektik heute, oder: Strukturen der Selbstnegation", in: D. Henrich, Hegels Wissenschaft der Logik, Stuttgart, Klett-Cotta, 1986, p. 153). 


\section{2 - Sobre o \& 81 da Enciclopédia e a contradição dialética}

É conhecida a distinção hegeliana entre os três momentos da totalidade lógica: o lado abstrato do entendimento, o dialético ou negativamente racional e o especulativo, ou positivamente racional. A divisão aparece a partir do \& 79 da Enciclopédia, sendo a dialética tratada especificamente no \& 81.

Se o entendimento é o pensar que atua sob condições limitantes, a razão é a compreensão de que estas limitações não são mais do que produto de sua própria atividade. Se há um limite para o conhecimento que o entendimento possui dos objetos, é porque desde sempre a razão está posta além destes limites, a demarcálos. Se para o entendimento tais limites são externos à sua atividade, para a razão eles são algo de interno. A Dialética mostrará em seu momento positivo o modo como se dá este ir além dos limites, que é justamente a atividade central da razão. ${ }^{8}$

Através do entendimento, os objetos são "[...] diferenciados e fixados para si, neste seu isolamento" (Enz, w. 8, p. 169). O entendimento fixa os objetos e trata de relacioná-los de modo externo. A identidade é seu princípio, pois entender é apreender um objeto em sua relação consigo mesmo, em suas determinações meramente formais. A forma é este universal que pervade uma multiplicidade de objetos, recolhendo-os em uma unidade que lhes é sempre imposta externamente. Enquanto idêntico consigo, um dado objeto é também idêntico com todos aqueles que possuem a sua forma. As suas diferenças para com os outros são neutralizadas via procedimento abstrativo. ${ }^{9}$

Ao contrário do entendimento, o momento dialético é justamente o reconhecimento da diferença e a necessária mediação do universal. Os objetos não são mais fixados, mas tornam-se fluidos. O limite não é mais simplesmente postulado, mas reconhecido e, portanto, superado. A relação entre os objetos deixa de ser externa e estes passam a ser vistos como momentos internos de uma mesma unidade.

8 Em Kant, esta função de superar os limites do entendimento é, ao contrário do que parece à primeira vista, algo fundamental. Não se trata aqui de superar os limites do entendimento utilizando ainda o mesmo modo característico da atividade deste, o que levaria inevitavelmente a antinomias. 0 superar dos limites do entendimento é funçăo das idéias reguladoras. Embora tais idéias não tenham qualquer validade para realizar o conhecimento objetivo, elas têm a tarefa crucial de garantir um fundamento último de legimidade da atividade do entendimento. As idéias regulam o uso do entendimento, sendo primeiramente as garantidoras dos limites desta atividade, e ao mesmo tempo regrando um uso não contraditório das categorias no conhecimento objetivo. Sem a dimensão de totalidade fomecida pela idéia de mundo, por exemplo, nenhuma compreensão dos fenômenos seria possivel; sem a idéia de alma, a própria subjetividade transcendental, garantidora última da unidade necessária do juízo sintético a priori, ficaria obscura. Cf. as análises de H. Krings, "Funktion und Grenzen der transzendentalen Dialektik in Kants Kritik der reinen Vernunft", in: G. Schönrich/l. Kato, Kant in der Diskussion der Modeme, Frankfurt am Main, Suhrkamp, 1996, p. 236-7.

9 Hegel cita como exemplo a identidade da lei no Direito. A lei dá conta de "n" número de casos que, sob a abstração prévia de suas diferenças especificas, são subsumidos por uma mesma norma: "[...] o juiz deve ater-se à lei, dar a sua sentença de acordo com ela, e não se deixar desviar por uma coisa ou outra; não admitir desculpa alguma [...]" (Enz, w. 8, p. 170). 


\section{1 - A contradição na base do elemento crítico ${ }^{10}$ da Dialética}

A esta fluidez corresponde, para Hegel, o momento negativo, crítico da dialética. Na verdade, a Dialética não se apresenta apenas neste momento negativamente racional, como é referido no \& 79; ela é, ao mesmo tempo, o elemento constitutivo do positivamente racional. Ela não traz em seu bojo apenas a contradição, enquanto marca da fluidez dos conceitos (determinações) do entendimento, mas é ela mesma o seu superar.

Mas certamente a Dialética mostra, em sua fase negativa, um de seus componentes mais originais. A Metafísica pós-kantiana só pode ser, para Hegel, filosofia dialética. Pois esta reconhece as dificuldades do proceder do entendimento para responder às questões centrais da Filosofia. A fase crítica da Dialética revela a incapacidade do entendimento em pensar as oposições centrais que estão na base do pensamento filosófico. O seu proceder recai sempre inevitavelmente em pressupostos externos não questionados, o que gera dogmatismo. ${ }^{11} \mathrm{Um}$ proceder não dogmático deveria superar as limitações externas características do entendimento, fundando limites imanentes em uma filosofia que teria como único pressuposto o seu próprio modo de proceder.

Não é por nada que vemos Hegel fazer uma referência, em adendo ao \& 81, às duas obras de que sua dialética se sente devedora: o Parmênides platônico e a Dialética Transcendental da Crítica da Razão Pura. Platão e Kant colocaram a Dialética em seu devido lugar, ao mostrar sua dimensão essencialmente crítica.

10 Este elemento crítico da Dialética foi diagnosticado com precisão por M. J. Adler. A Dialética seria, para este, fundamentalmente um método que combate formas dogmáticas de pensar. A sua interpretação incide, inclusive, contra as ambigüidades do sistema hegeliano, que apresenta a tendência a esgotar as oposiçōes em uma unidade definitiva. Hegel não escaparia da subversão do projeto originário da Dialética, recaindo no dogmatismo: "[...] seu defeito [da filosofia de Hegel], contudo, é que ela termina na idéia absoluta, na qual todas as oposiçöes são resolvidas. Isto submete a inconclusividade do processo dialético a um dogmatismo último" (Dialectic, New York, Harcourt, Brace \& Company, 1927, p. 233). A crítica me parece convincente, e pouco poderemos fazer com a filosofia hegeliana sem destitú-la de seu caráter necessitário e dogmático. A idéia de reinterpretar a contradição dialética, mostrando-a fundamentalmente como contradição por insuficiência está inserida dentro de um projeto mais amplo, que vincula o proceder dialético a um elemento empírico último, impedindo que esta se pretenda como ciência dedutiva. Compartilho, assim, da idéia de C. Taylor de reinterpretar a Dialética como método mais próximo à interpretação (com dimensão de historicidade) do que à ciência (entendida em seu sentido rigoroso, como modelo através do qual se pode fazer certas predições). Cf. C. Taylor, op. cit., p. 153.

11 Segundo Hegel, "a metafísica tomou-se dogmatismo porque devia admitir, segundo as determinações finitas, que de duas afirmações opostas [...], uma devia ser verdadeira, mas a outra falsa" (Enz, w. 8, p. 98). Ou seja, dogmatismo é o equivalente a aplicar o modo de proceder do entendimento ao nivel da justificação filosófica última. Só a Dialética é capaz de pensar a totalidade sem recair nas determinações fixas do entendimento, que exigem sempre uma relação externa entre si, não conseguindo resolver esta oposição. Tal extemalidade se revela ao entendimento, em última instância, através de supostos que são também eles extemos ao seu proceder. $\mathrm{O}$ entendimento depende sempre, então, de um momento inquestionado que reside fora de seu proceder, mas que ao mesmo tempo o condiciona; daí o dogmatismo. Uma atividade não dogmática é aquela que é capaz de tornar interno aquilo que para o entendimento é externo, levando a crítica da razão a uma radicalização que fundaria um modelo não dogmático de justificação última. Cf. as dificuldades de fundamentação próprias à filosofia kantiana devido à sua irreflexidade através das análises de M. A. de Oliveira, Sobre Fundamentação, Porto Alegre, Edipucrs, 1993, p. 28 e ss. 
Esta criticidade dialética é algo que mergulha fundo na tradição, tendo sido desenvolvida de modo radical primeiramente pelos sofistas. O diálogo é a arte da argumentação que impede os interlocutores de caírem em um dogmatismo e, conseqüentemente, em um discurso monológico. A Dialética mostra, desde esta sua tão remota origem, a necessária abertura do discurso e sua dimensão intersubjetiva.

Este recurso à tradição é importante para mostrarmos o vínculo entre o elemento negativo da Dialética e o conceito de contradição. Em suas origens mais remotas a contrađição é a marca da alteridade discursiva que nunca pode ser esgotada e eliminada via discurso monológico. $O$ dizer em contra é mantido e glorificado pela arte da contradição ${ }^{12}$ dos sofistas.

É claro que este elemento meramente negativo da Dialética será logo criticado pela filosofia socrático-platônica. Platão elaborará uma obra gigantesca cuja função central será justamente a compreensão de elementos que escapam ao ceticismo embutido na argumentação sofística. A teoria das formas e a ontológia da primeira fase das obras de Platão procuram justamente marcar esta distância em relação às origens sofísticas da Dialética.

Mas Platão nunca deixará de ver na Dialética este elemento negativo e voltará a utilizá-lo com uma força surpreendente justamente contra o modo de pensar que ele mesmo havia erguido, como uma muralha protetora, contra o negativismo sofístico. O Parmênides marcará na obra platônica a volta do poder negativo da Dialética.

Neste diálogo surgirá pela primeira vez esta dimensão fluida dos conceitos a que se refere Hegel no \& 81 da Enciclopédia. Os conceitos que expressam as oposições centrais da Ontologia - como uno e múltiplo, forma e matéria, etc. -, que eram tratados pela primeira fase platônica como opostos excludentes, passarão a ser vistos como correlativos nas obras maduras. ${ }^{13} \mathrm{~A}$ Dialética do Parmênides pode ser considerada negativa, pois ela não revela ainda a possível conciliação das oposições, mas mostra apenas seu caráter paradoxal. A primeira ontologia platônica, fortemente dualista, tratava de conferir verdade e necessidade a apenas um dos lados das oposições: as formas são universais e unas, a matéria é singular e múltipla; as formas são logicamente estruturadas, a matéria é momento destituído de logos. O Parmênides simplesmente marcará o paradoxal de um tal projeto dualista levado às últimas conseqüências. Ao pretendermos pensar a unidade isolada do uno, ou não conseguimos afirmar nada, ou somos levados necessariamente a falar do múltiplo. Se queremos dizer o múltiplo, somos levados a dizer ou nada ou o uno.

A dialética do Parmênides traz apenas este elemento paradoxalmente negativo, pois não se vê conciliação possível entre as oposições. A força negativa derruba pretensões de um determinado modo de proceder, mas nada repõe em seu lugar.

Em Kant a Dialética terá um uso também crítico. As antinomias surgem naquele discurso que procura dizer a totalidade pressupondo ao mesmo tempo as li-

12 Segundo expressão recorrente no diálogo Sofista de Platão.

13 Cf. os argumentos que desenvolvo em prol desta tese em artigo a ser lançado pela revista Síntese Nova Fase. Aqui faço apenas referência a esta questão, não sendo este o momento de aprofundá-la. 
mitações imanentes ao proceder do entendimento, as formas puras do espaço e do tempo. A tentativa de pensar um conceito como mundo - que possui, como todos os conceitos centrais para a metafísica tradicional, uma dimensão de totalidade através do proceder do entendimento leva necessariamente a uma oposição não conciliada. O mundo tem limite no espaço e no tempo; o mundo é ilimitado no espaço e no tempo. ${ }^{14}$

As antinomias kantianas não revelam a falsidade necessária de tal discurso, mas apenas uma indecidibilidade. Não é possivel optar por qualquer uma das duas oposições, ambas permanecem como irrefutáveis.

A questão central para Hegel é: não seria possível postular um modo de proceder essencialmente diferente daquele próprio do entendimento, e que conseguisse conciliar esta oposição que era para Kant aparentemente inconciliável? O momento negativo da Dialética não conteria nele mesmo já a gênese de um tal proceder? As antinomias não revelam parte da verdade, ou seja, a necessária referência dos conceitos fundamentais da Metafísica a oposições originariamente correlativas?

É justamente a partir deste contexto que devemos entender 0 lado positivo que Hegel vê nas antinomias kantianas. Surge através desta reelaboração do criticismo kantiano uma dialética renovada, que tem na contradição o seu componente metódico central.

A contradição em Hegel tem, assim, suas particularidades. Este conceito significará, em primeiro lugar, a incapacidade que temos de afirmar apenas um dos lados destes pares de oposição que estão na base do pensar filosófico. No Parmênides não podemos afirmar nem o uno nem o múltiplo isolados um do outro. Em Kant não podemos reter nem a proposição "o mundo tem um limite no espaço e no tempo", nem a proposição a esta contrária.

Ao querer dizer um dos pares, por exemplo, o uno - no Parmênides - este mostra-se fluido e somos levados a afirmar o seu contrário; e vice-versa: "Platão mostra, em seus diálogos estritamente científicos, através do tratamento dialético em geral, a finitude de todas as determinações fixas do entendimento. Assim, ele deduz, por exemplo, do uno o múltiplo e mostra contudo como o múltiplo é apenas aquilo que se determina como uno" (Enz, w. 8, p. 174).

O mesmo ocorre nas antinomias kantianas. Segundo Hegel, "foi Kant aquele que, nos tempos modernos, trouxe de volta a Dialética à memória e a colocou de novo em sua dignidade, e isto através do processo já descrito das assim chamadas antinomias da razão, nas quais não se trata de modo algum de um mero vaivém entre razões e uma mera ação subjetiva, mas procura descrever como toda a determinação abstrata do entendimento, tomada apenas como ela se dá a si mesma, se converte imediatamente em sua oposta" (Enz, w. 8, p. 174).

A contradição é o sinônimo da falta lógica originária de cada um dos opostos em seu isolamento. A esta contradição chamamos contradição por insuficiência, ${ }^{15}$ cujas particularidades ainda veremos com mais detalhe no presente artigo.

14 Cf. Kant, Kritik der reinen Vemunft, B454-455: "O mundo tem um início no tempo, e está também encerrado em limites no espaço. / 0 mundo não tem início e nem limites no espaço mas é infinito tanto no tempo como no espaço".

Cf. E. Luft, Para uma crítica intema ao sistema de Hegel, p. 82 e ss. 
Esta mesma contradição indicava, já em sua origem dialógica, a incapacidade em permanecermos fechados em apenas um dos lados de uma oposição discursiva: o elemento intersubjetivo é ineliminável da prosa filosófica. Ela apenas reapare$\mathrm{ce}$ - mantendo suas características fundamentais - num âmbito que já não é mais apenas discursivo, mas sim lógico-especulativo.

Para mergulharmos a fundo no como desta contradição, devemos seguir a indicação fornecida pelo próprio Hegel para desvendar o seu sentido. Hegel apresenta o finito como caso paradigmático da contradição dialética.

\section{2 - A contradição e o conceito de finitude}

Ao definir este lado negativo da Dialética, no mesmo \& 81, Hegel relaciona-o com o finito e, conseqüentemente, com a contradição do finito, um termo cuja elucidação será central para discernirmos o como do procedimento dialético: "A reflexão é, antes de tudo, o ir além da determinidade isolada, e um relacionar desta consigo mesma, através do qual esta se põe em relação, apesar de ser mantida em seu valor isolado. A Dialética é, ao contrário, este ir além imanente, no qual a unilateralidade e limitação das determinações do entendimento se apresenta como aquilo que ela é, ou seja, como sua negação. Todo o finito é isto: o superar-se a si mesmo" (Enz, w. 8, p. 172-3).

É importante investigarmos esta contradição que está na base da fluidez dos conceitos. Em primeiro lugar, por que aparece neste contexto a vinculação com o conceito de finitude? Hegel está tomando aqui, como aliás também em outros contextos, a contradição da finitude como caso paradigmático da contradição dialética. Poderemos compreender melhor o tipo de contradição que aqui incide a partir da análise do capítulo sobre a finitude na Lógica. Lá Hegel afirma que "[...] as coisas finitas existem, porém sua relação até si mesmas consiste em que se referem a si como negativas, e precisamente nesta auto-referência a si se lançam para fora, além de seu ser" (WL, w. 5, p. 139).

O finito representa 0 caso paradigmático da contradição dialética. Ele possui uma contradição interna que o impulsiona além de si mesmo. ${ }^{16}$ Aí reside a idéia da processualidade da Dialética. A fixidez das determinações finitas é substituída por sua fluidez imanente, por causa da contradição.

A contradição do finito possui aqui duas características:

1. a negação de si mesmo;

2. o ir além, para fora de si mesmo.

Neste momento eminentemente crítico da Dialética, o negativamente racional, aquilo que para o entendimento era fixo, sob a ótica da Dialética torna-se fluido. Aquelas oposições que mutuamente se excluíam tornam-se mutuamente referentes, embora ainda de modo meramente negativo.

16 No \& 421 da Enciclopédia, Hegel trará novamente a idéia da contradição do finito: "Essa ligação do singular e do universal é uma mescla, porque o singular é um ser que está como fundamento, e permanece firme ante o universal, ao qual é ao mesmo tempo referido. Ela é, portanto, a contradição multilateral: em geral das coisas singulares [...] e da universalidade [...]. Aqui incide, propriamente, a contradição do finito através de todas as formas das esferas lógicas [...]" (Enz, w. 10, p. 210). 
Ao mostrar esta fluidez dos conceitos, Hegel está lançando as bases de uma nova compreensão do conceito de contradição e ao mesmo tempo reintroduzindo o método dialético como modo de proceder que conseguiria superar os paradoxos em que havia caído o proceder do entendimento.

Já haviamos descrito algumas das características da contradição dialética. Cabe agora aprofundarmos a investigação deste conceito, para compreendermos 0 como e o porquê desta contradição do finito que está no núcleo do momento negativo da Dialética.

\section{3 - O que é a contradição dialética?}

Percebemos, em primeiro lugar, que a contradição dialética não se dá entre termos opostos. Daí a primeira diferenciação entre contradição dialética e contradição lógico-formal. Esta última é, em sua base, uma contradição que se dá entre dois termos ou proposições contraditórias [p e p]. Ora, a contradição do finito se dá neste na sua relação consigo mesmo. Há aqui, portanto, uma autonegação e não uma negação de outro; ${ }^{17}$ ou seja, a negação dialética que está na base da contradição é imanente ao próprio conceito [ou proposição] tratado, não se dando na sua relação externa com outro conceito [ou proposição]. Este é o como fundamental da contradição dialética.

Ora, se estas duas formas de contradição se diferenciam de modo tão cabal, também sua gênese necessariamente será diferente. Temos, então, um porquê diverso que está na base do surgimento de ambas as contradições. Sabemos que a gênese da contradição lógico-formal está na afirmação simultânea de predicados opostos a um mesmo sujeito sob o mesmo aspecto [p e $\sim p$ ]. Temos presente, também, que a contradição dialética se diferencia, em primeiro lugar, da contradição lógico-formal justamente por não se dar entre predicados (ou conceitos), mas em um predicado (ou conceito) consigo mesmo. Mas qual a gênese da contradição dialética?

Já em Platão esta se dava, como vimos, na incapacidade de um dos termos opostos em ser afirmado em seu isolamento. Em Kant se torna ainda mais explícito que a contradição surgia por uma incapacidade de qualquer uma das duas proposi-

17 Sendo assim, a forma de negação inerente à contradição do finito não coincide com o conceito fundamental de negatividade que D. Brauer encontra na filosofia de Hegel. Brauer considera a contradição como "[...] esta relação de reciproca exclusão e complementaridade de dois extremos de uma oposição bipolar [...] ou A é não-B e B é não-A" (cf. "Negación y negatividad en Hegel", in: Escritos de Filosofia, Buenos Aires, Centro de Estudios Filosóficos, 1994, p. 112). Mas a negação fundamental para a Dialética - que tem na contradição do finito seu caso paradigmático - não é negação excludente e externa, mas autonegação. Por outro lado, não há dúvida de que o finito só se constitui a partir da negação do infinito - no sentido de que o par finito/infinito só pode ser compreendido em sua relação de exclusão/complementaridade: exclusão naquilo que possuem de unilateral, e complementaridade naquilo em que encontram sua unidade. Mas este movimento duplo só tem lugar ao nível da síntese, na qual não se dá a gênese da contradição, mas sim o início do processo de sua superação. A meu ver, Brauer apresenta sua definição de modo mais preciso quando afirma: "A contradição [...] surge quando estas expressōes (ser, nada, etc.), que só funcionam como predicados ou modificadores de predicados, são tomadas como substantivos, 'substratos' na linguagem de Hegel, com sentido próprio independente da oposição de que formam parte". A contradição surge ao se conceber como totalidade um conceito que constitui apenas um lado de uma oposição fundamentalmente complementar [ou correlativa]. 
ções em afirmar-se como predicado de um sujeito de totalidade. O mundo não é nem apenas limitado no espaço e no tempo, nem ilimitado no espaço e no tempo.

O substrato fundamental das predicações realizadas na Dialética transcendental é um conceito de totalidade, aquilo que Hegel posteriormente denominará de absoluto. A contradição surge de uma tentativa frustada de afirmar qualquer uma das oposições em seu isolamento como predicado último do absoluto.

Este uso será central para a dialética hegeliana. A contradição não significará, para Hegel, apenas um momento falso, a ser descartado por qualquer um que queira realizar um discurso verdadeiro. Ela é muito mais do que isto: é a marca da necessária referência mútua das oposições fundamentais que residem na base do pensamento filosófico.

A Dialética mostra-se, assim, não apenas como o momento negativamente racional, mas ainda como o especulativamente racional. E mais: como o absoluto é para Hegel fundamentalmente unidade de opostos, as oposições não são jamais eliminadas, mas sim superadas e guardadas, e a insuficiência dos opostos nunca é plenamente esgotada. A síntese nega a unilateralidade dos opostos, mas não a oposição como tal; ela não é algo estanque, mas a superação constante da insuficiência imanente à oposição.

A contradição, então, não pode ser vista, em Dialética, como algo a ser excluído de todas as formas do discurso racional Mas isto não deve nos surpreender, pois não se trata aqui, de modo algum, da contradição lógico-formal. A indicação deste modo positivo de manifestação da contradição dialética (que chamo então de contradição sintética, ${ }^{18}$ aquela contradição que permanece mesmo na síntese dos opostos como algo inesgotável e intrínseco à atividade da razão) só vem destacar o quanto esta tem de diferente da contradição lógico-formal.

Perceberemos melhor o uso positivo da contradição no método dialético através de uma análise breve do começo da Lógica hegeliana.

\subsection{1 - A contradição e seu uso no começo da Lógica}

Todos os conceitos da Lógica de Hegel podem ser concebidos como predicados do absoluto. O próprio Hegel nos diz no \& 86 da Enciclopédia, que o ser "[...] é afirmado como predicado do absoluto, assim se dá a primeira definição deste: 0 absoluto é o ser" (Enz, w. 8, p. 183). Mas poderíamos dizer mais: todas as afirmações do sistema de Hegel tem como intenção dizer o absoluto. $\mathrm{O}$ absoluto, por outro lado, não é algo evanescente, ou a totalidade de todas as coisas possiveis e existentes: ele é fundamentalmente totalidade presente, efetiva. ${ }^{19}$

Desde o começo da Fenomenologia nos deparamos com a idéia de uma totalidade intencionada. Na certeza sensivel, a consciência quer dizer (meinen) a singularidade apontada. Mas este experimento falha, pois a singularidade apontada não

18 É deste modo que devemos entender o uso hegeliano da contradição como síntese entre identidade e diferença, na Lógica, Doutrina da Essência.

19 Quando Hegel nos fala, na Fenomenologia, que "o verdadeiro é o todo" (p. 24), ele não fala de uma totalidade abstrata. Cada momento de síntese alcançado pela atividade da consciência, desde a certeza sensível, é totalidade, cuja verdade em sua plenitude será alcançada no ápice das mediações, no saber absoluto. 
se garante como totalidade. Na percepção, a consciência quer dizer a universalidade, pois esta é "[...] seu principio em geral" (PhG, p. 93). Mas também este experimento falha, pois a universalidade é apenas um momento de uma unidade maior que a abarca.

A Fenomenologia procura nos mostrar que as oposições fundamentais que constituem a atividade da consciência, na busca de conhecer o mundo e a si mesma, devem ser vistas como correlativas: oposições que são momentos de uma unidade abrangente. Universalidade e singularidade são momentos do universal concreto; sujeito e objeto são momentos da atividade lógica da consciência, que é unidade fundamental de sujeito e objeto. A totalidade, ou o absoluto, é, em sua verdade, unidade de opostos.

À Fenomenologia foi reservada a tarefa de criticar os "[...] erros que, por obstruírem o acesso à filosofia, são abandonados na entrada da mesma (WL, w. 5, p. 38), ou seja, superar a falsa concepção do senso comum, que vê sujeito e objeto em oposição excludente. O saber absoluto é a reconciliação de sujeito e objeto, concebidos em unidade mútua.

À Lógica, por sua vez, caberá a prova de que o absoluto é fundamentalmente unidade de opostos; 0 absoluto é conceito: processo de autodeterminação e síntese de opostos. Este o significado mais íntimo da Dialética apresentada na Lógica de Hegel. Esta não é mais do que uma reinterpretação crítica dos conceitos fundamentais da tradição metafísica, mostrando-os como oposições correlativas e não excludentes. Conceitos que eram tratados pela tradição como incompatíveis passam a ser entendidos como momentos complementares de uma unidade maior que os abarca.

A Doutrina da Essência é dos capítulos mais críticos da filosofia ocidental, pois Hegel tratará aqui de romper todo um modo de pensar que era típico da tradição, que concebia os conceitos fundamentais como excludentes: essência e aparência, universalidade e singularidade, forma e matéria, necessidade e contingência, uno e múltiplo, substância e acidente. Todas estas oposições começam a ser vistas dentro de uma circularidade que se revelará como a alma do processo de autodeterminação da idéia absoluta no ápice da Lógica.

Para a tradição, a substância , a essência, a universalidade, a necessidade, etc., eram os conceitos que expressavam a verdade, enquanto os termos negativos eram deixados de lado na fundamentação última dos sistemas. É Hegel que tratará de romper esta postura.

Se a Lógica de Hegel é uma lógica do absoluto, a sua tarefa fundamental é mostrar a inconsistência de predicar como verdade do absoluto apenas um dos lados destas oposições básicas.

O método dialético contém, assim, o absoluto como sujeito de todas as predicações, a totalidade como a meta intencionada em cada um dos passos do sistema. Afirmar como totalidade o ser isolado, sem qualquer outra determinação, é dizer algo completamente indeterminado: o nosso experimento fracassa, pois se mostra inconsistente. Por outro lado, dizer o contrário do ser, ou o nada, também é inconsistente: o nada não se sustenta em qualquer afirmação. $O$ devir é o primeiro conceito que cumpre efetivamente com aquilo que intencionamos dizer: ele se basta como totalidade de sentido, reunindo em si a oposição correlativa do ser e do nada. 


\subsection{2 - O elemento pragmático da contradição}

A contradição por insuficiência revela a dimensão pragmática do método dialético. Ela mostra, em primeiro lugar, a falta de cada um dos conceitos em seu isolamento, referindo-os à totalidade (ou ao absoluto). O absoluto é visado ao predicarmos dele apenas um dos lados da oposição. Mas esta predicação não se cumpre, pois, ao fazermos uma afirmação unilateral, estamos dizendo apenas um dos momentos do absoluto. Há uma contradição entre aquilo que pretendíamos dizer ao falarmos do absoluto e aquilo que nossa proposição de fato realizou.

O elemento pragmático da contradição dialética foi demonstrado de forma original por W. Wieland, que ofereceu uma das contribuições mais efetivas para solucionar o porquê da contradição dialética em artigo de $1978,{ }^{20}$ cujo argumento central foi desenvolvido posteriormente por V. Hösle. ${ }^{21}$

Tratando justamente o problema do começo da Lógica, Wieland inicia mostrando o erro de se confundir contradição dialética e contradição lógico-formal: "Apenas compreendemos mal a Hegel, se entendemos sob a sua [o seu termo] 'contradição' exatamente a relação entre elementos de pares de proposição do tipo $\mathrm{p}$ e não-p" ${ }^{22}$ Segundo Wieland, a contradição dialética conteria no fundo um elemento pragmático: uma proposição como 'o ser é o absoluto' apresenta uma contradição, pois nela se dá uma discrepância entre "o que ela afirma e o que ela é (respectivamente o que ela faz) enquanto afirma algo". ${ }^{23}$ Há uma discrepância, portanto, entre o que queremos afirmar através da proposição - ou seja, que o ser é idêntico ao absoluto - e o que de fato fazemos ao expressá-la - determinamos o ser como diferente do absoluto. O objetivo da Lógica de Hegel é encontrar o conceito que "é ele mesmo aquilo que ele intende", ou seja, a idéia absoluta.

Sendo assim, aqueles conceitos que não cumprem minimamente aquilo que está sempre sendo intencionado pela atividade da razão, ou seja, uma dimensão de totalidade, possuem uma insuficiência lógica: a contradição não mostra a incompatibilidade entre os conceitos - como seria o caso em uma afirmação do tipo $p$ e $\sim p$-, mas a inconsistência de sua afirmação isolada, unilateral; tais conceitos são um lado de uma oposição entre correlativos.

A contradição dialética é, a meu ver, em sua dimensão mais fundamental, contradição por insuficiência, ela indica a falta ${ }^{24}$ que possui um conceito ao não corresponder com a intenção de totalidade que possui a atividade racional. Se afirmamos um conceito em sua unilateralidade e intencionamos com isto dizer o todo, surge uma discrepância entre aquilo que pretendemos dizer e o que de fato dizemos. Ao percebermos tal contradição, procuramos superá-la concebendo o conceito analisado como momento de uma totalidade maior.

20 W. Wieland, "Bemerkungen zum Anfang von Hegels Logik", in: R. P. Horstmann, Seminar: Dialektik in der Philosophie Hegels, Frankfurt am Main, Suhrkamp, 1978, p. 194-212.

21 V. Hösle, Hegels System. Hamburg: Felix Meiner, 1988, p. 156 e ss.

22 Wieland, op. cit., p. 196.

23 Wieland, op. cit., p. 196.

24 A idéia da insuficiência como motor da Dialética não é apenas típica de Hegel, encontrando sua gênese mais remota na própria dialética platônica: Platăo trata a falta ( $\varepsilon \vee \oint \varepsilon\llcorner\alpha)$ do bem como motor do processo dialético que está na base do amor. 


\subsection{3 - Os três modos distintos de manifestação da contradição dialética}

Podemos agora fazer uma breve recapitulação. Vimos que a contradição dialética possui, em primeiro lugar, um elemento fortemente crítico, que tornará fluidos os conceitos fixos do entendimento. A contradição mostrará o erro de se pensar as oposições que estão na base da conceituação filosófica como mutuamente excludentes.

Mostramos ainda que a contradição dialética possui ao mesmo tempo um elemento positivo, sendo incorporada por Hegel ao âmago mesmo do método dialético. Ela não pode de modo algum ser confundida com a contradição lógico-formal, que tem sempre e apenas um caráter negativo.

A Dialética para Hegel apresenta-se tanto no momento negativamente racional, como no positivamente racional, ou especulativo. A contradição não é apenas a marca do erro de um determinado tipo de proceder, mas já contém em si a possibilidade de sua superação.

A contradição dialética não pode ser plenamente compreendida se não tomarmos ela mesma como um conceito fluido. Ela apresenta três modos diferentes de manifestação, que revelam também três sentidos diferentes. Em primeiro lugar, ela se apresenta como contradição por insuficiência, mostrando a falta de cada um dos conceitos ao não poder realizar, isolado, um sentido pleno. $O$ seu sentido exige a referência a seu oposto. Se tal falta pode ser superada, e enquanto ela é superada, temos então o uso positivo da contradição, ou contradição sintética. A contradição é aqui eminentemente positiva, ${ }^{25}$ pois é a alma mesma do processo dialético: "a raiz de todo o movimento e vitalidade" ( $W L$, w. 6, p. 75). A síntese dialética nunca esgota a oposição, ela não é a unidade acabada resultante da síntese dos opostos, mas unificação através da resolução constante - que constitui no fundo uma tarefa inacabável - da contradição por insuficiência. O absoluto não é, mas está sendo.

Por outro lado, há ainda um terceiro modo em que aparece a contradição dialética. Enquanto a contradição por insuficiência não é superada, surge então uma disrupção, que aparece, por exemplo, nos paradoxos em que cai o entendimento

${ }^{25}$ A não-compreensão dos três modos diferentes de manifestação da contradição dialética pode facilmente levar a mal-entendidos. É usual as críticas ao uso hegeliano da contradição em seu sentido efetivamente positivo. McTaggart havia proposto a substituição do conceito de contradição como síntese de identidade e diferença (Doutrina da Essência, na Lógica) por essencialidade estável (cf. A Commentary on Hegels Logic, New York, Russell \& Russell, p. 116). V. Hösle não aceita o uso hegeliano deste termo para designar aquelas "[...] determinaçőes concretas, cuja autocontradição não se pode mais provar" (Hegels System, p. 178). Mas Hegel sem dúvida usa o conceito de contradição ao falar de momentos sintéticos: a contradição não está apenas superada no fundamento, mas também conservada nele: "A oposição e sua contradição está aqui tanto superada (aufgehoben) quanto conservada (erhalten)" (WL, v. 6, p. 69). A meu ver estas criticas ao uso hegeliano são infundadas: se fosse possivel anular toda a forma de contradição na síntese dos opostos, o absoluto não seria processo de superação, mas resolução plena da insuficiência, e portanto imobilidade. Seria inevitável recairmos em uma estrutura dogmática. Devemos levar a sério a acusação de dogmatismo descrita por M. J. Adler: não estaríamos "entregando a inconclusividade do processo dialético a um dogmatismo último"? (Dialectic, op. cit., p. 233) A idéia da contradição por insuficiência exposta neste artigo impede, por definiçảo, a possibilidade de um sistema conclusivo, exaustivo. A Dialética é, de modo imanente, abertura e não fechamento: "[...] para o filósofo a inevitável frustração da dialética nảo é uma tragédia; sua inconclusividade é o símbolo da possibilidade infinita" (M. J. Adler, op. cit., p. 247). 
ao tentar pensar a totalidade, nas antinomias de Kant. Portanto, nos casos em que a contradição não é resolvida, esta é potenciada, surgindo a contradição disruptiva, o aparecimento do irracional.

Um dos casos paradigmáticos de disrupção é tratado no capítulo sobre a Liberdade Absoluta e o Terror da Fenomenologia. Aí Hegel trata do momento de uma liberdade não mediada, em que a vontade de um indivíduo singular - que é apenas momento de uma totalidade - assume o lugar da vontade do espírito de um povo: "Como nessa obra universal da liberdade absoluta a autoconsciência singular não se encontra como substância existente, tampouco ela se encontra nos atos singulares e ações individuais de sua vontade. Para que o universal chegue a um ato, ele precisa se concentrar no uno da individualidade, e pôr no topo uma consciência singular [...]. Mas com isto todos os outros singulares são excluídos do todo deste ato, e nele só têm uma participação limitada; de tal modo que 0 ato não seria 0 ato da autoconsciência universal efetiva. A liberdade universal não pode produzir, assim, nenhuma obra positiva; [...] ela é apenas a fúria do desvanecer" $(P h G$, p. 435$6)$.

O terror na política é a conseqüência justamente da ascensão de um indivíduo ao poder supremo e a submissão de todos à sua vontade. Não ocorre, aqui, a devida mediação entre as vontades singulares e o seu reconhecimento como momentos da vontade universal (o espírito de um povo). A contradição por insuficiência de que goza a vontade de cada indivíduo singular - por ser apenas um momento dentro da mediação das vontades - não é resolvida, mas potenciada.

A vontade singular se inverte em vontade universal: a fluidez dos conceitos. $\mathrm{E}$ a vontade universal daquele que tem a voz de comando é apenas uma unidade excludente, que afasta de si a vontade de todos os demais. O resultado desta potenciação da insuficiência é, justamente, a contradição disruptiva: "a fúria do desvanecer" que está na base do terror.

Curioso que Hegel trate este aparecer do irracional - como, aliás, também o fará no caso da guerra entre os Estados singulares, na Filosofia do Direito - como um momento necessário na autodeterminação do Espírito. Não há uma reflexão mais detida de Hegel sobre o momento da disrupção e suas conseqüências. Hegel tinha confiança demais na astúcia da razão. 